\title{
A Comparative Study of Suburbanization in United States and China
}

\author{
Sainan $\operatorname{Lin}^{1}$ \\ ${ }^{1}$ Department of Geosciences, University of Massachusetts Amherst, the United States \\ Correspondence: Sainan Lin, Department of Geosciences, University of Massachusetts Amherst, 01003, United \\ States. Tel: 1-413-801-6836. E-mail: sainan.lin@gmail.com
}

\author{
Received: October 10, 2014 Accepted: October 19, 2014 Online Published: November 25, 2014 \\ doi:10.5539/jgg.v6n4p132 URL: http://dx.doi.org/10.5539/jgg.v6n4p132
}

\begin{abstract}
Suburbanization as a topic of urban geography is always an important subject. This study responds to the recent call for a "comparative (re) turn in urban studies" by comparing suburbanization in the United States and China. The comparative perspective offered here focuses on the "differences" rather than the similarities. This study clarifies one of the significant differences between the United States and China, suburbanization has not weakened the functionality of city centers in China in the way it did in the United States: 1) unlike the United States, suburbanization has not weakened the economic function of city centers in China because of the different administrative jurisdiction system; 2 ) when suburbanization is taking place, city centers gain even more political powers in China; 3 ) despite the fact that people moved out to the suburbs, city centers are still the places where the best living condition and most job opportunities exists.
\end{abstract}

Keywords: comparative studies, suburbanization, city centers, United States, China

\section{Introduction}

The suburbanization that started on a significant scale in the 1920s and accelerated after World War II in the United States and Europe is still a focus of interest in both urban research and planning (Bourne, 1996; Clapson \& Hutchison, 2010; Hanlon, Short, \& Vicino, 2011; Kirby \& Modarres, 2010; Pacione, 2009; Schaffer, 1970). Since the 1978 economic reforms (Note 1) in China, some metropolises, along with on-going urbanization, show a trend of suburbanization. Due to its prominent and inevitable impact on urban structure and social and economic development, this suburbanization has aroused wide concern among scholars, planners, and politicians, and also generated a rich body of literature (Feng, 2001; Fleisher, 2010; Silu Li \& Tang, 1998; Wang \& Zhou, 1999b; Wenyu Wu, 2010; T. Zhang, 2000b; Zhou, 1995; Zhou \& Logan, 2008). The views on suburbanization of Chinese cities vary; however, most of them draw conclusions based on the western theories, especially those of the United States. The United States, the world's first predominantly suburban nation (Harris \& Lewis, 2000; Jackson, 1985), serves as typical research material and as a comparable model. Are such models applicable to the developing countries? Or are those theories based on the experience of capitalist countries applicable to those post-socialist countries? What happens to the urban-suburban relationship to the transitional China that is transferring from soviet-style socialism to a market system? Without denying that the mature theories and rich research products of Western countries on suburbanization indeed provide abundant and useful information, I argue here that they are not adequate to explain the process of suburbanization in China.

Responding to the recent call for a comparative (re) turn in urban studies, this study emphasizes the figure of "difference" itself when conducting the comparative research (Jacobs, 2012; McFarlane \& Robinson, 2012). I attempt to clarify one of the significant differences between the United States and China on the topic of suburbanization, that is, tremendous suburban growth in the United States during the peak period of the 1950s and 1960s was at the expense of the city center and led to urban decay, but no such devastating impact on the city center in China has been realized during the suburbanization period since 1980s. Chinese city centers are still dominant and they flourish. This study analyzes the different systems of the United States and China in terms of economic, political, and social functions. It is necessary to recognize the uniqueness of Chinese suburbanization here, which could give references for China's government to better manage the on-going process of suburbanization, provide models and experience to other developing countries or post-socialist countries, and to be complimentary to the existing theories of suburbanization which are mostly from western countries. 


\section{Material Studied}

The process of suburbanization, as a significant perspective of urban studies, has long held the attention of urban researchers, from Burgess's early ecological model of urban social structure suggesting that the outward growth of cities was associated with the movement of more affluent groups from the city center to the periphery (Burgess, 1924), to Kenneth Jackson's Crabgrass Frontier: the suburbanization of the Unites States which also viewed this process in terms of the residential preferences of the middle classes for "homes in the park" (Jackson, 1985), to more recent accounts, such as Walker and Lewis' call for revision of these perspectives by emphasizing three key processes: urban geographical industrialization, investment in real estate, and political guidance by business and government leaders (Walker \& Lewis, 2001). .

No matter what the opinions about the suburbanization process are, the development of the city center has an undeniable and complex relationship with the process of suburbanization (Beauregard, 2006; Hayden, 2003; Mills \& Price, 1984) Both Kaassen et al. (1981) and van den Berg et al. (1982), for example, employed the concept of a cycle of urbanization (Note 2), in which they defined suburbanization as a phase that whereby the urban ring grows at the cost of the urban core. In other words, suburbanization contributed to the decay of the city center. This is the common view for North American and Western researchers. However, is this theory universally true when applied to countries other than North America and Western countries? No, at least not for China.

In fact, from the Chicago School's urban sociology, to the Los Angeles School of post-modern geography, paradigms about city and the "standard" urban theories have been established mainly based on the North American and Western European urban experience (Abu-Lughod, 1975; Dear, 2001, 2005; Judd \& Simpson, 2011). Many scholars have tried to settle the western urban theory and non-western, non-urban development division, which led a recent renaissance of research on comparative urban studies (Mcfarlane, 2010; Nijman, 2007; Schiller, 2012). However, a high percentage of existing comparative researchers either attempt to find similarity between two or more societies, or adopt western theories to explain non-western societies. By extracting information from existing literature, this paper contributes to urban studies by adding a more systematic comparison between the United States and China in terms of suburbanization. By avoiding assumptions of current theories, I focus on the differences between the United States and China in terms of suburbanization, and contribute to the urban theory from experiences of socialist countries.

\section{Area Descriptions}

\subsection{Suburbanization in United States}

In the United States, city centers and suburbs linked in a symbiotic yet competitive relationship together constitute an economic system - the metropolitan economy (Stanback, 1991). During the 1950s and 1960s, the substantial demand for housing and a need to generate employment after the Great Depression and WWII, provided incentives for suburban growth. Federal agencies liberalized the loan-lending policies, which encouraged new home and home-ownership in the suburban area-furthering middle class flight from the city center and spread to suburban area (Beauregard, 1993; Bourne, 1996; Palen, 1995; Thorns, 1972). For example, the new Veteran Administration (VA) loan guarantees made loans available to veterans at low interest rates, below conventional mortgages, with no money down and with a twenty-five-year repayment schedule (Palen, 1995). Meanwhile, the federal government financed construction of a metropolitan freeway system which enhanced individual mobility, and enabled the new suburbanites to commute from the city center to suburbs. Industrial and commercial services moved out to the suburbs to pursue lower price land and labor force prices (Baldassare, 1986; Berg, Drewett, Klaassen, Rossi, \& Vijverberg, 1982; Bradbury, Downs, \& Small, 1982).

According to data of eight large metropolitan areas in the United States, Stanback and Knight argue that the average annual growth rates of populations in city centers is a negative $0.21 \%$ while a substantial $6.78 \%$ increase in suburban population during 1950s to 1960s; the average annual growth rates of manufacturing and retail employment in the city center are negative $1.13 \%$ and $0.52 \%$, respectively, in comparison to a positive $5.02 \%$ and $7.69 \%$ increase in the suburbs (Thomas M. Stanback \& Knight, 1976). In addition, the city center not only lost its population, job opportunities and economic predominance to the suburbs, but also its social advantage with poor and declining communities predominating (Pacione, 2009). As Beauregard's work on the United States cities strongly states, suburbs choked and decayed the city centers and let them become "Urban Dinosaurs" (Beauregard, 1993, 2006), Short also argued that the other side of mass suburbanization was a war waged against the city centers (Short, 2006). 


\subsection{Suburbanization in China}

Given the experience of the United States, it seems we can draw the conclusion that suburbanization is a stage "when the urban ring (commuter belt) grows at the cost of the urban core (physically built-up city), which is a position in the book Urban Geography (Pacione, 2009). Does suburbanization happen only when the growth of the suburbs decays the city centers?

Since reform and opening up policy was introduced to China during the 1980s, suburbanization first took place in large cities, such as Beijing (Zhou, 1997; Zhou \& Ma, 2000), Shanghai (Siming Li, 1996), Guangzhou (Wei \& Zhou, 1995), Hangzhou (Feng \& Zhou, 2005). A loss of population in the city centers was first noticed as a signal of the suburbanization process in the 1980s in China, and followed by a relocation of factories and enterprises. In the case of the U.S' experience of suburbanization, some of the scholars call for attention from the public and scholars alike that we should learn lessons from western countries, resisting the massive sprawl in the fringe areas of cities which would lead to the decline of the city center (Jin \& Gong, 1998; Silu Li \& Tang, 1998). Others believe that China has gone through the process of suburbanization but in a unique Chinese way (Zhou \& Ma, 2000) and they even suggesting suburbanization to solve the crowded city center problem (Feng, 2001; Zhou, 1995).

After the mid-1990s, the process of suburbanization in China became obvious. Many scholars, both from home and overseas, made comparisons of Chinese suburbanization and the western countries' suburbanization (Cervero \& Day, 2008; Dai, 1994; Zhou, 1996). For example, Fleischer points out that there are three kinds of people who relocated to the suburbs in China, migrants from other provinces (because they could not afford houses in the city centers), professionals and workers from old state-owned companies, but mostly those from the middle class who moved to the suburbs in the United States during the substantial suburbanization period (Fleisher, 2010). He further argues there were different driving forces of suburbanization between China and the United States. In addition, some scholars differentiate the process and consequences of the two nations. The beginning of the suburbanization process in China, was the same as the earlier process in the United States, that factories, warehouses, residential places in the city centers moved to the suburban areas for cheaper land (Wang \& Zhou, 1999a; Zhou, 1997). However, the difference is that the land in the city centers in China has been replaced by more profitable tertiary service such as commerce, banking, hotels and office buildings and with certainly more modern design. More importantly, the suburb and the city center in China are under the administration of the same city government. Thus, both the land revenue and taxes from the suburb and the city center are given to the city government, which funds to improve the service of the city centers (T. Zhang, 2000a)

\section{Methods}

This study addresses two major research questions: 1) has Chinese suburbanization weakened the city centers? Why? 2) what are the differences between the United States and China's suburbanization? A comparative method will be utilized as the main strategy to understand if the suburbanization weakened Chinese city centers in the same way as the U.S suburbanization did. Specifically, this research will compare both situations in the aspects of economic, social and political function changes to the city centers. The historical periods of suburbanization that I focus on are 1950s-1960s for the United States and 1990s-2000s for China. Therefore, most of data is collected from existing literature, and archives in both U.S. and China.

\section{Comparison and Results}

There are distinct scenes of the city centers and suburbs during 1950s-1960s in United States and 1990s-2000s in China: for the United States, after WWII, population loss, the physical deterioration of housing and shops, the rising racial segregation and conflict, the collapse of urban land values, soaring crime rates, have all, at one time or another, plagued the city centers, while that period suburb boomed (Beauregard, 1993; Bloom, Reed, \& Reed, 1952) . In China, however, the suburbs grew rapidly since the economic reform: new neighborhoods are built up, and upgraded and multilevel fast roads extended to suburbs where gated housing estates and development zones are scattered. Meanwhile, skyscrapers mushroom in city centers, Central Business District (CBDs) or financial streets, bar street and night-time entertainment places, boulevards and city squares, high-tech parks and economic development zones characterize the new Chinese cities (Gaubatz, 1995; F. Wu, 2007; F. Wu, Xu, \& Yeh, 2006). Based on this observation, the following part addresses economic, political and social aspects of cities and resulting differences in the United States and China.

\subsection{Economic Function}

\subsubsection{Land Value and Revenue}

Unlike in the United States where suburban growth has been shaped under a stable regulatory environment and a 
constant capitalist system, Chinese suburbanization was driven by Chinese transformation from a central-planned economy to a market economy. During the 1980s, following the economic reform and open up, land reform is another milestone for China's development in the history (Hin, 1996; Lin, 2009; Yeh \& Wu, 1996). Before the land reform, there were two kinds of land, one was state-owned urban land, the other was collective-owned rural land. People had unlimited use of the land under the permission of the state without paying, but could not transfer the land use rights between land users. In 1988, the first land use right of 5,000 square meters was "sold" in Shenzhen for 50 years, unveiling the prelude of state-owned land use reform. Since then, under the guarantee of land ownership that belongs to the state, land use rights could be transferred, leased, and mortgaged according to certain price, duration and purpose restrictions. Therefore, land revenue became one of the main income sources for the city government. As government-led suburbanization is taking place in China, there has not been a reduction in the value of the urban land or a lessening of the land revenue in the city center. Instead it has expedited the shift of land use from industrial to commercial and other tertiary uses. In fact, the construction of high-rise buildings and housing raised the land value in the city centers. Also, prices of land use rights vary, with the result that in the urban fringe areas and the suburbs the cost of land remains lower (Fleisher, 2010; Gaubatz, 1995). Therefore, substantial agricultural land was transferred to industrial or residential land. Simultaneously, this land gained much higher value, which in turn contributed to the city government's revenue. In other words, city governments and current land occupiers have been able to generate large profit from the land-leasing system. Additionally some of the city income has been used to improve urban infrastructure and for urban renewal that has made the city a better place to live and work. In short, instead of urban environmental decline and the shift of fiscal resources to the suburbs that US city centers have experienced, the city centers in China flourish at the same time when suburbanization is taking place. (Zhou \& Ma 2000).

\subsubsection{Tax Revenue}

Tax revenue is another contributor for the city center's thriving economy. During the peak period of suburban growth in the United States, along with the "white flight", city centers lost their tax base to the suburbs. Because of the different administrative jurisdiction systems, no such devastating impact on the city centers' tax revenues has resulted from suburbanization in China (Zhou \& Ma, 2000), China's administrative system puts rural counties under the jurisdiction of cities and uses the household registration system ( $h u k o u$ ) to classify individuals as non-agricultural or agricultural residents (K. W. Chan, 2007; R. C. K. Chan \& Zhao, 2003). As a result, Chinese "suburbanization", in fact, has taken place entirely within the areas that are under the administrative jurisdiction of the cities themselves - that is, though people moved out of the city centers to the suburbs, they still contribute taxes to the city government.

\subsubsection{Job Opportunities}

During the peak time of suburbanization in the United States, urban factories closed, moved to the suburbs or laid off workers, caused a severe loss of jobs in the city centers. Not surprisingly, the resident flight also spurred additional job loss through the lessoning demand for public and private services and for such goods as housing and groceries (Beauregard, 2006). In addition, not only did the old theatres, cinemas, restaurants, and grocery stores move to the suburban areas, but also new shopping malls, theatres, office buildings were built which in turn stimulated more job opportunities in the suburbs. Cities were losing jobs to suburbs, and suburban employment grew faster than city center employment. On the contrary, since China's 1978 reform, millions of villagers migrated from rural areas to city centers to search of job opportunities. From 1982 to 2000, there were about 0.2 billion people migrating from rural areas to city centers. This rural migration has burgeoning after 2000. The economic development of city centers provide more job opportunities than the incipient developing suburbs.

\subsection{Political Function}

In the United States, the growth of the suburbs also weakened the political function. During the suburbanization period, the metropolitan areas of the United States were divided into city centers and suburbs which then led to governmental fragmentation (Hanlon et al., 2011; Peterson, 1973). In the 1970s, the numbers of people who lived in the suburbs surpassed the number who lived in the city centers. Generally speaking, the political jurisdictions of cities expand as they grow in population. The expanding suburbs diminished the political power of the city centers, which also weakened the ability of cities to influence the share of government spending allocated to them and their residents (Downs, 1994). However, this is not the case in Chinese suburbanization where the whole suburbanization process has taken place within the jurisdiction of cities themselves - that is, the suburbs and the city centers are under the authority of same government.

More importantly, because city governments in China are always located in the city centers, keeping the vibrant 
development of city centers is their priority. Unlike the United States where the suburbanization is result of individuals' wish for better living conditions, Chinese suburbanization is directed by government policy (Weiping Wu \& Gaubatz, 2012). The city government implemented a market-oriented urban land use system, facilitated the decentralization of urban industries, and promoted the construction of suburban housing, thus, serving as a powerful engine driving city centers' development.

\subsection{Social Function}

\subsubsection{People and Neighborhoods}

As suburbanization accelerated in the United States during the 1960s, the city centers experienced absolute population loss, especially loss of their Caucasian population, which also is known as "white-flight". These "white people" who were working and middle class moved out to the suburbs looking for better living conditions such as being close to the nature, and owning a single house with a big yard. Those who were left in the city centers were mostly poor as a result of high unemployment rate and low-wage jobs. Such social disadvantage was one of the city center problems in the United States, but in China as Zhou and Logan acknowledge, "suburbanization in China could not be based primarily on lifestyle choices by more affluent people", they argue that it is not the reality for many of China's new suburbanites who moved out of the city centers for better housing, more space and good environment (Zhou \& Logan, 2008). The reality is that most of these out-migrants are low-income people, such as migrant rural workers (nongmin gong), or old state-owned company workers, who either cannot afford housing in the city centers or moved out with their factories (Fleisher, 2010; Wenyu Wu, 2010). In other words, most of the middle class and elites are still living in the city centers, and contribute to the city centers' prosperity.

\subsubsection{Government Services}

As deterioration proceeded in the city centers of the United States, the fiscal resources available to city governments shrank even though their needs increased. According to Down (1994), the costs of providing police and fire protection, judicial systems, public hospitals, and jails are much higher in low-incomes areas than in higher-incomes areas (Downs, 1994). With the middle class leave the poor people concentrated in the city center, the city government became less and less able to provide opportunities for their residents that are equal to those provided in suburbs. Thus a great many people in city centers failed to develop the skills, knowledge, basic values, and behavior patterns that would enable them to be productive members of society (Downs, 1994).

\subsubsection{Crime Rate and Living Environment}

Compared to the United States where the city centers congested were plagued by crime and racial segregation, the city centers in China have a healthier, safer and better living environment. In China, the ingrained urban-rural dichotomy (chengxiang eryuan jiegou) makes a huge difference between urban and rural areas. Urban areas, are considered more advanced than rural areas because of the economic reform, and enjoy most of the development priorities. People who live in urban areas not only have better living conditions such as adequate infrastructures and favorable services, but they also have more chances to obtain better educations. The common public perception is that most of the crime is attributable to the migrants who originally came from rural areas (Nielsen \& Smyth, 2008; Weiping Wu \& Gaubatz, 2012, Forthcoming 2012; L. Zhang, Messner, Liu, \& Zhuo, 2009). In order to reduce the crime rates in city centers, most of those criminals (who usually are poor and less-educated) were relocated to the urban fringes under the government-led policies (Weiping Wu \& Gaubatz, 2012).

\section{Conclusion}

Suburbanization as a topic of urban geography is always under the study by the scholars. Unlike most existing literature about Chinese suburbanization which usually applies the theory of western countries, in this study, I clarify one of the significant differences between the United States and Chinese suburbanization: suburbanization has not weakened the functionality of city centers in China in the way it did in the United States, further suggest that theories based on the unique Chinese situation is important not only for China's development, but also for those other post-socialist countries. By gathering information from existing literature, this study contributes to urban studies by adding a more systematical comparison between the United States and China in terms of suburbanization.

Specifically, this study examines the differences in three aspects: first, unlike the United States, suburbanization has not weakened the economic function of city centers in China. Chinese suburbanization has taken place entirely within the areas that are under the administrative jurisdiction of the cities themselves. Thus, instead of losing tax base and land revenue to suburban governments as was the case in the United States, the city governments not only gained more taxes by displacement industrial and residential land to commercial land but 
also obtained more land revenue by renting the suburban land. Secondly, when suburbanization is processing, city centers gain even more political powers. Finally, despite the fact that people moved to the suburbs, city centers are still the places where the best living condition and most job opportunities exist.

By analyzing both cases in terms of economic, political and social functions, this study analyzes the differences between U.S. and China in a broad view. More in-depth and thorough research will be needed in the future study, such as comparison between cities of different sizes and economies.

\section{Acknowledgments}

I would like to thank Professor Piper Gaubatz, Stan Stevens, Eve Vogel, Qian Yu and Laurie Brown from University of Massachusetts Amherst for their comments and suggestions for the first manuscript.

\section{References}

Abu-Lughod, J. L. (1975). The Legitimacy of Comparisons in Comparative Urban Studies: a Theoretical Position and Application to North African Cities. Urban Affairs Review, 11(1), 13-35.

Baldassare, M. (1986). Trouble in paradise: the suburban transformation in America. New York: Columbia University Press.

Beauregard, R. A. (1993). Voices of decline: the postwar fate of US cities. Cambridge, Massachusetts: Blackwell.

Beauregard, R. A. (2006). When America became suburban. Minneapolis: The University of Minnesota Press.

Berg, L. v. d., Drewett, R., Klaassen, L. H., Rossi, L., \& Vijverberg, C. (1982). A study of growth and decline. Oxford: Pegasus.

Bloom, M. T., Reed, T. H., \& Reed, D. D. (1952, October 11). Does your city suffer from suburbanites? Collier's Weekly, 130, 18-20.

Bourne, L. S. (1996). Reinventing the suburbs--Old Myths and New Realities. Progress in Planning, 46(3).

Bradbury, K. L., Downs, A., \& Small, K. A. (1982). Urban deciline and the future of American cities. Washington D.C.: The Brookings Institution.

Burgess, E. W. (1924). The growth of the City: An Introduction to a Research Project. Publications of the American Sociological Society, 18, 85-97.

Cervero, R., \& Day, J. (2008). Suburbanization and transit-oriented development in China. Transport Policy, 15(5), 315-323. http://dx.doi.org/10.1016/j.tranpol.2008.12.011

Chan, K. W. (2007). Misconceptions and Complexities in the Study of China's Cities: Definitions, Statistics, and Implications. Eurasian Geography and Economics, 48(4), 30.

Chan, R. C. K., \& Zhao, X. (2003). The Relationship between Administrative Hierarchy Position and City Size Development in China. GeoJournal, 56, 16.

Clapson, M., \& Hutchison, R. (Eds.). (2010). Suburbanization in global society (Vol. 10): Emerald Group Publishing.

Dai, S. (1994). Lun Shanghaishi de chengshi kongjian zhihuan. Urban Problems.

Dear, M. (2001). From Chicago to LA: making sense of urban theory. London: Sage.

Dear, M. (2005). Comparative urbanism. Urban Geography, 26, 247-251.

Downs, A. (1994). New visions for Metropolitan America. Washington D.C.: Brookings Institution Press.

Feng, J. (2001). The Progress and Prospect of The Research on Suburbanization in China. Human Geography, 16(6), 30-35.

Feng, J., \& Zhou, Y. (2005). Suburbanization and the Changes of Urban Internal Spatial Structure in Hangzhou, China. Urban Geography, 26(2), 10.

Fleisher, F. (2010). Suburban Beijing: Housing and consumption in comtemporary China. Minneapolis: University of Minnesota Press.

Gaubatz, P. (1995). Chaning Beijing. Geographical Review, 85(1), 18.

Hanlon, B., Short, J. R., \& Vicino, T. J. (2011). Cities and suburbs: new metropolitan realities in the US. Lodon and New York: Routledge. 
Harris, R., \& Lewis, R. (2000). The geography of North America cities and suburbs 1900-1950. Journal of Urban History, 27(3), 262.

Hayden, D. (2003). Building suburbia: green fields and urban growth, 1820-2000: Pantheon.

Hin, L. L. (1996). Privatization of urban land in Shanghai. Hong Kong: Hong Kong University.

Jackson, K. T. (1985). Crabgrass frontier: the suburbanization of the United States. New York: Oxford University Press.

Jacobs, J. (2012). Commentary-Comparing Comparative Urbanism. Urban Geography, 33, 940-914.

Jin, Z., \& Gong, X. (1998, May 21). zhongkeyuan yuanshi wu liangyong huyu fangzhi chengshi jiaoquhua xianxiang. Guangming ribao.

Judd, D. R., \& Simpson, D. (Eds.). (2011). The city revisited: urban theory from Chicago, Los Angeles, and New York. Minneapolis: University of Minnesota Press.

Kirby, A., \& Modarres, A. (2010). The Suburban Question: An introduction. Cities, 27(2), 65-67. http://dx.doi.org/10.1016/j.cities.2010.01.001

Li, S. (Ed.). (1996). Zhongguo quyu jingji fazhan mianmina guan. Taibei, Hongkong.

Li, S., \& Tang, Y. (1998). Chengshihua buneng zai hua xiaqu le. Suburbanization must be stopped. Urban Development, 8, 25-26.

Lin, G. C. S. (2009). Developing China: land, politics, and social conditions. London: Routledge.

Mcfarlane, C. (2010). The Comparative City: Knowledge, Learning, Urbanism. International Journal of Urban and Regional Research, 34(4), 725-742.

McFarlane, C., \& Robinson, J. (2012). Introduction-Experiments in Comparative Urbanism. Urban Geography, 33(6), 765-773. http://dx.doi.org/10.2747/0272-3638.33.6.765

Mills, E. S., \& Price, R. (1984). Metropolitan Surburbanization and Central City Problems. Urban Economics, $15,1-17$.

Nielsen, I., \& Smyth, R. (2008). Who Wants Safter Cities? Perceptions of Public Safety and Attitude to Migrants Among China's Urban Population. International Journal of Law and Economics, 28(1), 46-55.

Nijman, J. (2007). Introduction-Comparative Urbanism. Urban Geography, 28(1), 1-6.

Pacione, M. (2009). Urban geography: a global perspective (3rd ed.). New York: Routledge.

Palen, J. J. (1995). The suburbs. NYC: McGraw-Hill, Inc.

Peterson, S. M. D. a. P. E. (1973). Urban policies. New York: Praeger Publishers.

Schaffer, F. (1970). The new town story. London: MacGibbon \& Kee.

Schiller, N. (2012). A Comparative Relative Perspective on the Relationships Between Migrants and Cities. Urban Geography, 33(6), 879-903. http://dx.doi.org/10.2747/0272-3638.33.6.879

Short, J. R. (2006). Alab aster cities: urban US since 1950. Syracuse, NY: Syracuse University Press.

Stanback, T. M. (1991). The new suburbanization: challenge to the central city.

Thomas M. Stanback, J., \& Knight, R. (1976). Suburbanization and the City. NJ: Allanheld, Osmun \& Co.

Thorns, D. C. (1972). Suburbia. London: MacGibbon.

Walker, R., \& Lewis, R. D. (2001). Beyond the Crabgrass Frontier: Indurstry and the Spread of North Amrican Cities, 1950-1950. Journal of Historical Geography.

Wang, F., \& Zhou, Y. (1999a). Modeling Urban Population Densities in Beijing 1982-1990: Suburbanization and Its Causes. Urban Studies, 36(2), 17.

Wang, F., \& Zhou, Y. (1999b). Modelling Urban Population Densities in Beijing 1982-90: Suburbanization and its Causes. Urban Studies, 36(2), 17.

Wei, Q., \& Zhou, C. (1995). Guangzhou shiqu renkou yanbian yu chengshi guihua. Urban Planning and the Demographic Changes in Guangzhou City. Urban Planning Forum, 4.

Wu, F. (2007). China's emerging cities: the making of new urbanism. London: Routledge. 
Wu, F., Xu, J., \& Yeh, A. G.-O. (2006). Urban development in post-reform China: state, market, and space. London: Routledge.

Wu, W. (2010). Zhongmei Chengshi Jiaoquhua Fazhan Bijiao Yanjiu. [Comparison of Suburbanization Between US and China and Policy Implications to China]. Yunnan Geography Environment Research, 22(3), 6.

Wu, W., \& Gaubatz, P. (2012). The Chinese City. London: Routledge.

Wu, W., \& Gaubatz, P. (Forthcoming 2012). The Chinese city: Routledge.

Yeh, A. G.-o., \& Wu, F. (1996). The New Land Development Process and Urban Development in Chinese Cities. International Journal of Urban and Regional Rearch, 20, 24.

Zhang, L., Messner, S. F., Liu, J., \& Zhuo, Y. A. (2009). Guanxi and Fear of Crime in Contemporary Urban China. British Journal of Criminology, 49, 472-490.

Zhang, T. (2000a). Land Market Forces and Government's Role in Sprawl: the Case of China. Cities, $17(2), 13$.

Zhang, T. (2000b). Land market forces and government's role in sprawl: The case of China. Cities, 17(2), 123-135. http://dx.doi.org/10.1016/s0264-2751(00)00007-x

Zhou, Y. (1995). Chengzhen jiaoquhua he ni chengzhenhua. Suburbanization and counter-urbanization. City, 4, $7-10$.

Zhou, Y. (1996). Beijing de jiaoquhua ji yinfa de sikao. On the suburbanization of Beijing. [ON THE SUBURBANIZATION OF BEIJING]. SCIENTIA GELGRAPHICA SINICA, 3.

Zhou, Y. (1997). On the Suburbanization of Beijing. Chinese Geographical Science, 7(3).

Zhou, Y., \& Logan, J. R. (2008). Growth on the edge: the New Chinese Metropolis. In J. R. Logan (Ed.), Urban China in Transition (pp. 140-160). Oxford: Blackwell.

Zhou, Y., \& Ma, L. (2000). Economic Restructuring and Suburbanization in China. Urban Geography, 21(3), 205-236.

\section{Notes}

Note 1. Zhou and Ma (2000) discussed the stage of suburbanization in China, and concluded that Chinese suburbanization has been a direct consequence of the 1978 economic reforms aiming at the creation of a system of market socialism.

Note 2. They envisaged that there are four stages of urban development: Urbanization, suburbanization, disurbanization or counterbanization, and reurbanization. L. Klaassen, W.Molle and J. Paelinck (1981) Dynamics of Urban Development New York: St Martin's Press; L.van den Berg, R. D rewet, L.Klaassen, L.Rossi and C.Vijverberg (1982) A Study of Growth and Decline Oxford: Pegasus.

\section{Copyrights}

Copyright for this article is retained by the author(s), with first publication rights granted to the journal.

This is an open-access article distributed under the terms and conditions of the Creative Commons Attribution license (http://creativecommons.org/licenses/by/3.0/). 